\title{
MEWUJUDKAN PERSEROAN TERBATAS (PT) PERSEORANGAN BAGI USAHA MIKRO KECIL (UMK) MELALUI RANCANGAN UNDANG-UNDANG TENTANG CIPTA KERJA
}

\author{
(Materializing Single-Member Private Limited Liability Company for Micro \\ and Small Business trough Job Creation Bills) \\ Muhammad Faiz Aziz \\ Sekolah Tinggi Hukum (STH) Indonesia Jentera \\ Puri Imperium Office Plaza, Unit UG 15, Jalan Kuningan Madya Kav. 5-6 \\ Jakarta Selatan, DKI Jakarta, 12190 \\ e-mail:muhammad.aziz@jentera.ac.id \\ Nunuk Febriananingsih \\ Badan Pembinaan Hukum Nasional \\ Jalan Mayjen Soetoyo No. 10 Cililitan Jakarta Timur \\ e-mail: febrianasdalh1@gmail.com
}

\begin{abstract}
Abstrak
Pemerintah membentuk RUU tentang Cipta Kerja yang bertujuan untuk memudahkan iklim berusaha di Indonesia. RUU ini masuk dalam daftar prioritas Prolegnas Tahun 2020 dan diharapkan dapat meningkatkan peringkat kemudahan berusaha (Ease of Doing Business) Indonesia di dunia khususnya terkait indikator memulai usaha (starting a business) yang tertinggal dari negara tetangga dan menjadi peringkat kelima di tingkat ASEAN. Untuk itu, Pemerintah menciptakan terobosan agar setiap orang dapat dengan mudah memulai usaha khususnya bagi Usaha Mikro dan Kecil (UMK). Sejumlah klaster RUU sudah disusun dan salah satu dari sub klaster tersebut adalah terkait dengan pembentukan badan usaha. Dalam rangka mewujudkan kemudahan berusaha tadi, terdapat kebutuhanuntuk membentuk satu jenis badan usaha baru khususnya bagi UMK berupa Perseroan Terbatas (PT) yang didirikan oleh satu orang. PT perseorangan diharapkan dapat memberikan kemudahan bagi pelaku UMK dalam membentuk perusahaan dengan persyaratan dan permodalan minimum. Dengan menggunakan metode yuridis normatif, artikel ini membahas konsep PTperseorangan dengan membandingkan pengaturan dengan negara lain, diantaranya adalah negara-negara Uni Eropa, United Kingdom, Malaysia, dan Singapura,sehingga dapat menjadi pembelajaran bagi Indonesia apabila hendak mewujudkan hal tersebut. Dari hasil kajian dibutuhkan pengaturan yang tepat dan komprehensif dalam rangka mewujudkan PT bagi UMK dalam rangka mendukung kemudahan berusaha di Indonesia.
\end{abstract}

Kata Kunci: PT perseorangan, usaha mikro dan kecil, kemudahan berusaha, omnibus law, memulai berusaha

\begin{abstract}
Government are creating an Omnibus Bill on Jobs Creation. The bill has been listed on top priority one to be discussed in 2020 and it is expected to improve business climate as well as improving Ease of Doing Business (EODB) rank, especially for the indicator of "starting a business" that is lagging behind from neighbouring countries. Creating prospective idea is necessary to improve easiness in starting a business especially for Micro and Small Enterprises (MSEs). This bill has some clusters and one of them is related to the establishment of business entities. To materialize this, there is a need to form a new type of business entity for MSEs i.e. Single-Member Private Limited Liability Company (PT) that can be established by one single member. The future form of this limited liability company is expected to ease micro and small businesess in forming a company with minimum capital and requirements. The experiences and regulatory arrangements in the European Union, United Kingdom, Malaysia and Singapore shall be studied for Indonesia's lesson learned to materialize the new type of company. Surely, proper and comprehensive arrangements are necessary in order to realize PT for MSEs in order to support the ease of doing business in Indonesia.
\end{abstract}

Keywords: single-member private limited liability company, micro and small business, ease of doing business, omnibus law, starting a business 


\section{A. Pendahuluan}

Pada 20 Oktober 2019, Presiden Joko Widodo menyampaikan pidatonya mengenai rencana membentuk Omnibus Law $^{1}$ dalam bentuk Rancangan Undang-Undang (RUU) tentang Penciptaan Lapangan Kerja dan Pemberdayaan Usaha Mikro Kecil dan Menengah (UMKM). ${ }^{2}$ RUU ini dibentuk untuk memudahkan iklim berusaha di Indonesia. ${ }^{3}$ Dalam perjalanan, dua rencana RUU ini kemudian digabung menjadi satu RUU dengan nomenklatur cipta kerja. Urgensi RUU cipta kerja adalah adanya dinamika perubahan global yang perlu direspon secara cepat dan tepat, sebab tanpa reformulasi kebijakan maka pertumbuhan ekonomi akan melambat. Dengan RUU Cipta Kerja diharapkan terjadi perubahan struktur ekonomi yang mampu menggerakkan semua sektor untuk mendorong pertumbuhan ekonomi mencapai 5,7\%-6\% melalui: penciptaan lapangan kerja yang berkualitas, peningkatan investasi sehingga dapat meningkatkan income dan daya beli sertamendorong peningkatan konsumsi dan peningkatan produktivitas yang akan diikuti peningkatan upah sehingga dapat meningkatkan income, daya beli, dan konsumsi. Apabila hal ini tidak dilakukan, maka lapangan pekerjaan akan pindah ke negara lain yang lebih kompetitif, penduduk yang tidak bekerja akan semakin tinggi, dan Indonesia dapat terjebak dalam jebakan negara berpendapatan menengah (middle income trap) ${ }^{4}$. Oleh karena urgensitasnya yang demikian tinggi, RUU ini masuk dalam Program Legislasi Nasional (Prolegnas) 20192024 dan masuk sebagai salah satu RUU prioritas untuk dibahas dan disahkan pada $2020 .^{5}$

RUU Cipta Kerja secara dinamika menimbulkan kontroversi publik. Penolakan atas RUU ini pun muncul ke permukaan karena RUU Cipta Kerja dianggap lebih berpihak kepada usaha besar dan investasi asing. RUU ini pun dianggap mengabaikan kepada pengaturan pelindungan mengenai isu ketenagakerjaan, lingkungan hidup, dan sumber daya alam. ${ }^{6}$ Pemerintah dianggap hanya mengejar kenaikan peringkat kemudahan berusaha saja (Ease of Doing Business-EODB).

Terlepas dari dinamika pro kontra RUU Cipta Kerja, diantara materi yang akan diatur dalam RUU ini adalah mengenai: kemudahan

Istilah ini sering dikenal dengan Omnibus Bill. Omnibus Bill merupakan suatu rancangan undang-undang yang mencakup lebih dari satu permasalahan yang substantif yang hendak digabungkan atau disederhanakan menjadi satu RUU. Lihat The Law Dictionary, "What is Omnibus Bill", Featuring Black's Law Dictionary Free Online Legal Dictionary $2^{\text {nd }}$ Edition, https://thelawdictionary.org/omnibus-bill/, (diakses pada 31 Januari 2020).

2 Hendra Friana, "Jokowi Ajak DPR Buat UU Cipta Lapangan Kerja \& UU Pemberdayaan UMKM", Tirto, 20 Oktober 2019, https://tirto.id/jokowi-ajak-dpr-buat-uu-cipta-lapangan-kerja-uu-pemberdayaan-umkm-ej5G, (diakses pada 3 Februari 2020).

3 Rakyat Merdeka, "Dorong Iklim Investasi dan Daya Saing RI, Omnibus Law", RMcoid, Selasa, 24 Desember 2020, https://rmco.id/baca-berita/government-action/25164/dorong-iklim-investasi-dan-daya-saing-ri-omnibuslaw-segera-dirampungkan, (diakses pada 6 Februari 2020).

4 Satya Bhakti Parikesit, "Penjelasan RUU Cipta Kerja", (Makalah Disampaikan pada Seminar Menyikapi Omnibus Law, Pro dan Kontra RUU Cipta Lapangan Kerja, Fakulta Hukum Universitas Indonesia, Depok, 6 Februari 2020).

5 Dewan Perwakilan Rakyat Republik Indonesia, "Program Legislasi Nasional Prioritas", http://www.dpr.go.id/ uu/prolegnas, diakses pada 2 Februari 2020.

6 Adhy Tea, 12 Alasan Masyarakat Sipil Tolak RUU Cipta Lapangan Kerja, Hukum Online, Sabtu 1 Februari 2020, https://www.hukumonline.com/berita/baca/lt5e3474fe03a84/12-alasan-koalisi-masyarakat-sipil-tolak-ruucipta-lapangan-kerja/, (diakses pada 10 Februari 2020). 
berusaha (bagi UMKM) dankemudahan, pemberdayaan, dan pelindungan UMKM. Hal ini mengingat bahwa UMKM merupakan tulang punggung perekonomian negara dengan jumlahnya mencapai 64,2 juta atau 99,99\% dari total pelaku usaha, kontribusi terhadap Produk Domestik Bruto (PDB) mencapai $61,07 \%$, dan penyerapan hingga 97\% total tenaga kerja Indonesia. ${ }^{7}$ Sebesar 98\% usaha mikro merupakan usaha informal dengan produktivitas yang sangat rendah. Rasio kewirausahaan Indonesia sebesar $3,4 \%$, sedangkan rasio kewirausahaan Malaysia sebesar 5,01\%. Dengan fleksibiitas pasar tenaga kerja, re-skilling, up-skilling, serta program kesejahteraan pekerja, maka produktivitas dan pendapatan UMKM akan dapat ditingkatkan. ${ }^{8}$ Salah satu usulan bentuk kemudahan berusaha adalah berupa pengaturan variasi bentuk Perseroan Terbatas (PT) yang sesuai dengan karakter Usaha Mikro dan Kecil (UMK). Bentuk hukum badan usaha ini tidak bisa dimanfaatkan oleh pelaku usaha menengah.Terkait hal ini, dalam Draf RUU Cipta Lapangan Kerja yang sudah diserahkan kepada DPR, dalam Pasal 153A draft rancangan undang-undang cipta lapangan kerja diatur bahwa:

(1) Perseroan yang memenuhi kriteria usaha mikro dan kecil dapat didirikan oleh 1 (satu) orang;

(2) Pendirian Perseroan untuk usaha mikro dan kecil dilakukan berdasarkan surat pernyataan pendirian yang dibuat dalam Bahasa Indonesia;

(3) Ketentuan lebih lanjut mengenai pendirian Perseroan untuk usaha mikro dan kecil diatur dengan Peraturan Pemerintah

PT yang sesuai dengan UMK ini dapat disebut dengan PT perseorangan karena dapat didirikan oleh satu orang. Model PT ini dikenal di United Kingdom (UK) dan Uni Eropa (EU) serta diterapkan juga di negaranegara Asia Tenggara seperti Malaysia dan Singapura. Istilah Single-Member Private Limited Liability Company atau SingleMember Company merupakan istilah yang digunakan dalam peraturan perundangundangan mereka sebagai kesamaan dengan PT perseorangan yang akan diusulkan untuk diatur. PT Perseorangan untuk UMK ini tidak memerlukan Akta Pendirian, akan tetapi hanya cukup pernyataan pendirian perseroan yang disahkan secara elektronik oleh Menteri Hukum dan HAM (biaya pengesahan dapat dibebaskan). ${ }^{9}$

Adanya usulan mengenai PT perseorangan ini berpotensi positif dalam rangka meningkatkan peringkat kemudahan berusaha Indonesia (EODB) dengan indikator "memulai usaha" (starting a business). Hal ini mengingat bahwa kemudahan pendirian PT menjadi salah satu tolok ukur dalam penilaian peringkat EODB. ${ }^{10}$ Persepsi mengenai pendirian PT yang mahal bisa

7 Kementerian Koperasi dan Usaha Kecil dan Menangah (UKM), "Perkembangan Data Usaha Mikro, Kecil, Menengah (UMKM) dan Usaha Besar (UB) tahun 2017-2018", http://www.depkop.go.id/uploads/laporan/1580223129_ PERKEMBANGAN\%20DATA\%20USAHA\%20MIKRO,\%20KECIL,\%20MENENGAH\%20(UMKM)\%20DAN\%20 USAHA\%20BESAR\%20(UB)\%20TAHUN\%202017\%20-\%202018.pdf, (diakses pada 30 Januari 2020).

8 Satya Bhakti Parikesit, Op., Cit., hlm. 17.

9 Satya Bhakti Parikesit, Op., Cit., hlm. 34

10 World Bank Group(1), Doing Business 2020: Comparing Business Regulation in 190 Economies, (Washington: The World Bank, 2020), hlm. 19 \& 21. 
terhapus apabila model PT perseorangan hadir. Selama ini, pendirian badan usaha lain seperti perusahaan perorangan, firma, atau persekutuan komanditer (Commanditaire Vennootcschaap-CV) dianggap relatif mudah dan murah. Bentuk hukum perusahaan perorangan dan CV merupakan bentuk hukum yang relatif banyak di Indonesia ketimbang bentuk PT bagi Usaha Mikro dan ecil.

Berangkat dari uraian singkat yang dikemukakan sebelumnya, penulis tertarik untuk melakukan kajian mengenai bentuk hukum PT perseorangan tersebut. Pengalaman negara-negara lain dalam mengatur mengenai hal ini bisa menjadi pembelajaran bagi Indonesia apabila hendak mengatur jenis PT seperti ini. Kehadiran bentuk PT perseorangan pada satu sisi dapat memberikan kemudahan bagi pelaku UMK, namun disisi lain juga berpotensi risiko khususnya bagi pihak ketiga atau kreditur. Pengaturan yang lebih berkualitas tentu saja diperlukan. Oleh karenanya, artikel ini dibuat untuk mengeksplorasi lebih jauh atas potensi pengaturan mengenai PT perseorangan agar mencapai keseimbangan antara kemudahan berusaha dan pelindungan pihak ketiga atau kreditur, bagaimana konsepsi, peluang, dan tantangan mengenai PT perseorangan dan Single-Member Private Limited Liability Company (SMC) dan studi komparatif pengaturan di negara EU, Malaysia, dan Singapura.

\section{B. Metode Penelitian}

Artikel ini dibuat berdasarkan hasil riset atau kajian dengan menggunakan metode riset kepustakaan dengan pendekatan normatif yuridis. Kajian ini bersifat deskriptif analitis kualitatif. Studi kepustakaan dijadikan sebagai metode riset ini mengingat kajian terhadap bentuk hukum PT perseorangan dapat dilakukan melalui penelusuran terhadap konsep, peraturan, dan implementasi melalui bahan hukum primer berupa peraturan perundang-undangan, bahan sekunder berupa buku, jurnal, berita, dan laporanlaporan resmiserta bahan tertier berupa kamus hukum dan bahasa.

\section{Pembahasan}

\section{Perusahaan Perseorangan, Perseroan Terbatas, dan Perseroan Terbatas untuk UMK}

Gagasan untuk membentuk dan mengatur tentang PT untuk UMK yang bisa didirikan oleh satu orang tidak lepas dari dua bentuk hukum usaha lainnya yaitu perusahaan perseorangan dan perseroan terbatas (PT). Perusahaan perseorangan dikenal juga dengan istilahsole proprietorshipatau sole trader. Bentuk usaha ini adalah bentuk usaha yang paling sederhana untuk dibuat. Zainal Asikin dan Wira Pria Suhartana mendefinisikan perusahaan perseorangan sebagai perusahaan yang dilakukan oleh satu orang pengusaha. ${ }^{11}$ Perusahaan ini didirikan oleh satu orang, dimodali oleh satu orang, dan dijalankan oleh satu orang. ${ }^{12}$ Perusahaan ini pun tidak ada kewajiban untuk terdaftar, sehingga pembubarannya pun tidak memerlukan persetujuan pihak lain. Istilah yang dikenal di publik seperti Perusahaan Dagang (PD) atau Usaha Dagang (UD) pada dasarnya merupakan

11 Zainal Asikin \& Wira Pria Suhartana, Pengantar Hukum Perusahaan, Edisi Pertama, (Jakarta: Prenada Media Group, 2016), hlm. 6.

12 Hendri Raharjo, Hukum Perusahaan, Cetakan Ke-1, (Yogyakarta: Penerbit Pustaka Yustisia, 2009), hlm 26. 
perusahaan perseorangan. ${ }^{13}$ Terhadap perusahaan perseorangan, tidak ditemukan pengaturan baik dalam Kitab Undang-Undang Hukum Dagang (KUHD) maupun peraturan perundang-undangan lainnya. ${ }^{14}$ Sementara itu, bentuk hukum usaha PT merupakan bentuk usaha berbadan hukum yang cukup populer digunakan pelaku usaha. ${ }^{15}$

Secara terminologi, PT yang merupakan gabungan dua kata "perseroan" dan "terbatas" mempunyai makna masing-masing. Perseroan menunjuk kepada modal yang meliputi sero atau saham. ${ }^{16}$ Kata "terbatas" merujuk kepada tanggung jawab pemegang saham yang sebatas nilai nominal saham yang dimilikinya. ${ }^{17}$ PT merupakan asosiasi pemegang saham (atau bahkan seorang pemegang saham bila dimungkinkan hukum negara tertentu) yang diciptakan oleh hukum dan diberlakukan sebagai manusia semu (artificial person) oleh pengadilan. ${ }^{18}$ Badan usaha ini merupakan badan hukum dan memiliki kekayaan yang terpisah dari pendirinya atau pemiliknya serta dapat melakukan hubungan hukum dalam hal perolehan/peralihan kekayaan dan berurusan ke pengadilan. ${ }^{19}$ Dalam Undang-Undang Nomor 40 Tahun 2007 tentang Perseroan Terbatas, PT adalah badan hukum yang merupakan persekutuan modal, didirikan berdasarkan perjanjian, melakukan kegiatan usaha dengan modal dasar yang seluruhnya terbagi dalam saham dan memenuhi persyaratan yang ditetapkan dalam undangundang ini serta peraturan pelaksanaannya. ${ }^{20}$ PT merupakan badan usaha dengan tanggung jawab yang terbatas bagi para pemegang sahamnya.

PT perseorangan merupakan perusahaan perseorangan berbentuk badan hukum dengan tanggung jawab terbatas yang didirikan oleh satu orang dan dipimpin oleh satu orang direktur. Beihui Mao (2012) menyebutkan bahwa SMC merupakan perseroan terbatas yang memiliki satu pemegang saham yaitu orang pribadi (natural person) atau badan hukum (legal person). ${ }^{21}$ Model PT perseorangan ini merupakan perkembangan dari bentuk PT yang pada awalnya hanya boleh didirikan oleh dua orang atau lebih.

Chewaka (2016) menyebutkan bahwa pembentukan model PT perseorangan adalah hasil dari sifat natural keinginan setiap orang yang hendak membentuk perusahaan yang tanggung jawabnya terbatas, namun bisa didirikan oleh satu orang saja. ${ }^{22}$ Latty melengkapi pendapat ini dengan

\footnotetext{
Zainal Asikin \& Wira Pria Suhartana, Ibid., hal. 6-7.

Ibid.

15 Adrian Sutedi, Buku Pintar Perseroan Terbatas, Cetakan Ke-1, (Jakarta: Raih Asas Sukses, 2005), hlm. 7.

16 Ahmad Yani dan Gunawan Widjaja, Seri Hukum Bisnis: Perseroan Terbatas, (Jakarta: Raja Grafindo Persada, 2006), hlm. 1. Dalam Kamus Besar Bahasa Indonesia (KBBI) daring, makna kata sero adalah saham. Lihat Badan Pengembangan Bahasa dan Perbukuan Kementerian Pendidikan dan Kebudayaan, "Sero", KBBI Daring, https:// kbbi.kemdikbud.go.id/entri/sero, (diakses pada 7 Februari 2020).

17 Ahmad Yani \& Gunawan Widjaja, op.cit.

18 Ibid., hlm. 2.

19 Ibid.

20 Indonesia, Undang-Undang tentang Perseroan Terbatas, UU No. 40 Tahun 2007, Lembaran Negara Tahun 2007 No. 106, Tambahan Lembaran Negara No. 4756.

21 Beihui Mao, "A Comparative Study of Legal Framework for Single Member Company in European Union and China", Journal of Politic of Law, Vol. 5(3) 2012, http://dx.doi.org/10.5539/jpl.v5n3p1, hlm. 1-14: hlm.2.

22 Jetu Edosa Chewaka, Introducing Single Member Companies in Ethiopia: Major Theoritical and Legal Considerations, (Hamburg: Anchor Academic Publishing, 2016), hlm. 11.
} 
menyatakan bahwa argumentasi model PT yang bisa didirikan oleh minimal dua orang merupakan "legal idiosyncrasy" atau reaksi berlebihan saja. Menurutnya, tidak pernah ada "keajaiban dalam hal jumlah minimal pemegang saham". ${ }^{23}$ Maksud pendapat ini adalah bahwa terlepas berapapun jumlah pemegang saham, maju tidaknya perusahaan tidak pernah bergantung pada hal tersebut.

Senada dengan Chewaka dan Latty, sebetulnya KUHD Indonesia yang pertama kali melahirkan pengaturan PT hanya mengatur PT dengan model perjanjian dua orang atau lebih, namun tidak memberikan batasan definisi dari perusahaan dan PT itu sendiri. Maksud dari ketiadaan pemberian definisi ini adalah pembuat KUHD sudah terbiasa dengan bentuk usaha yang bervariatif dan berkehendak menyerahkan kepada dunia keilmuan dan yurisprudensi. Hal ini dianggap lebih baik ketimbang diatur dengan batasan yang ketat karena pengertian perusahaan dapat berkembang sesuai dengan dinamikanya. ${ }^{24}$

Di sejumlahnegara, model PT perseorangan demikian sudah ada juga dengan istilah SingleMember Private Limited Liability Company di EU dan UK, ${ }^{25}$ Sendirian Berhad (Sdn Bhd) di Malaysia, ${ }^{26}$ dan Private Limited Company
(Pte Ltd) di Singapura. ${ }^{27}$ Bahkan, menariknya negara-negara diantaranya seperti Uganda, ${ }^{28}$ Etihiopia, ${ }^{29}$ dan Pakistan $^{30}$ sudah mengenal dan mempunyai regulasi PT perseorangan. Lebih lengkap mengenai PT perseorangan di negara-negara lain akan dibahas dalam bagian berikutnya.

\section{Perseroan Terbatas Perseorangan di Berbagai Negara}

Dalam bagian ini, perbandingan pengaturan PT perseorangan di negara lain akan melihat kepada pengaturan di UK, EU, Malaysia, dan Singapura. Secara umum, kelima wilayah ini masing-masing mewakili soal tradisi hukum perusahaan (seperti UK), penerapan hukum dalam kawasan regional (Uni Eropa), dan peringkat memulai berusaha yang amat baik (Malaysia dan Singapura yang merupakan negara Asia Tenggara).

\section{a. Uni Eropa}

Uni Eropa merupakan kawasan yang memiliki regulasi mengenai PT perseorangan dalam konteks regional. Belum ada kawasan selain EU di dunia yang mempunyai pengaturan mengenai model perusahaan ini secara regional. Pertama kali, EU menerbitkan

23 Ibid., hlm 11-12.

24 Soekardono, Hukum Dagang Indonesia: Jilid I (Bagian Pertama), Cetakan ke-9, (Jakarta: Penerbit Dian Rakyat, 1982), hlm. 19-20. Menteri Kehakiman Belanda pada saat penjelasan mengenai KUHD ini dihadapan parlemen Belanda menyatakan bahwa KUHD ini hanyalah pedoman bagi perusahaan namun dengan tetap memberikan batasan penafsiran perusahaan sebagai pihak yang bertindak secara tidak terputus-putus dan terang-terangan dalam kedudukan tertentu untuk mendapatkan laba bagi dirinya sendiri.

25 Lihat Directive 2009/102/EC of the European Parliament and of the Council of 16 September 2009 in the area of company law on single-member private limited liability companies. Lihat juga United Kingdom Companies Act 2006 (Chapter 46).

26 Lihat Malaysia Companies Act 2016 (Act 777).

27 Lihat juga Singapore Companies Act 1967 (Chapter 50), last amended in 2006.

28 Uganda, The Companies (Single Member) Regulations 2016, Statutory Instruments 2016 No. 72, The Uganda Gazette No. 79, Vol CIX, 18 November 2016, Article 3 and 4.

29 Jetu Edosa Chewaka, op.cit., p. 3.

30 Awais Aftab, "Company Regisration in Pakistan as Single Member Company", Oly, 1 Juni 2017, https://oly.com. pk/company-registration-pakistan-single-member-company/, (diakses pada 8 Februari 2020). 
Company Law Directive (89/667/EEC) tentang perseroan terbatas perseorangan (singlemember private limited liability companies). Directive yang terbit pada 1989 ini sejarahnya bermula dari proposal yang dipresentasikan Komisi Eropa pada 1988. Dalam proposal tersebut disebutkan bahwa ada kebutuhan untuk mendorong pendirian dan pengembangan UMKM, mendorong semangat berwirausaha di kalangan komunitas, dan mendorong kemudahan akses wirausaha individu. ${ }^{31}$ Proposal ini pun didukung oleh hasil resolusi Konsil Eropa pada 1986 yang menggarisbawahi kebutuhan pembentukan usaha yang bisa didirikan atau dikelola oleh satu orang individu. ${ }^{32}$

Dasar hukum bagi PT perseorangan di EUsaat ini adalah Directive 2009/102/EC on the area of ompany law on single-member private limited liability companies. Directive ini menggantikan Company Law Directive (89/667/EEC). ${ }^{33}$ Regulasi ini merupakan regulasi pedoman bagi negara-negara anggota EU dalam mengatur PT perseorangan tanpa mengabaikan independensi atau kedaulatan bagi tiap-tiap negara anggota untuk mengaturnya. ${ }^{34}$ Setiap negara anggota boleh mengaturnya lebih lanjut atau menyisipkan aturan EU ini ke dalam undang-undang perusahaan mereka yang sudah ada. ${ }^{35}$
Tidak ada pengertian definitif atas PT perseorangan di Uni Eropa. Namun demikian, merujuk kepada Pasal 2 Directive 2009/102/ $E C$ on the area of company law on singlemember private limited liability companies, perusahaan yang didirikan satu orang dengan saham-saham dimiliki sendiri dan perusahaan dikelola oleh diri sendiri disebut sebagai singlemember private limited liability companies. ${ }^{36}$ Dalam PT model ini, pemegang saham dan direksi hanyalah satu orang. Proses pendirian PT perseorangan di Uni Eropa diserahkan kepada hukum pada negara masing-masing. Begitupun dengan bidang usaha dari PT tersebut dan struktur PT perseorangan, yang umumnya terdiri dari Rapat Umum Pemegang Saham (RUPS) dan direksi. Pemegang saham tunggal dapat menggunakan kewenangannya untuk menyelenggarakan RUPS dan mengambil keputusan untuk usahanya.

Terkait dengan konversi perusahaan tunggal menjadi PT biasa, Directive mengatur bahwasuatu PT perseorangan bisa tetap menjadi PT perseorangan atau akan beralih menjadi PT biasa ketika pendirinya merupakan pendiri pada sejumlah perusahaan lain atau PT perseorangan didirikan oleh badan hukum. ${ }^{37}$ Directive ini mendorong negara anggota untuk membuat ketentuan khusus mengenai kebebasan pengaturan tersebut atau bahkan

31 Commission of The European Communities, Proposal for a Twelfth Council Directive on Company Law Concerning Single-Member Private Limited Companies, COM(88) 101 final-SYN 135, (Brussels, 18 May 1988), hlm. 3.

32 Ibid.

33 Lihat Pasal 9 Directive 2009/102/EC on the area of ompany law on single-member private limited liability companies yang mencabut Company Law Directive (89/667/EEC).

34 Lihat Pasal 1 Directive 2009/102/EC on the area of ompany law on single-member private limited liability companies.

35 Alex Roney, EC/EU Fact Book, 6 Edition, (London: Kogan Page, 2000), hlm. 149.

36 Pasal 2 ayat 1 Directive 2009/102/EC on the area of ompany law on single-member private limited liability companies

37 Pasal 2 jo. Pasal 6 Directive 2009/102/EC on the area of ompany law on single-member private limited liability companies. 
memberikan sanksi denda atau penalti bagi pemegang saham atau perusahaan yang bersangkutan terkaitlarangan pendirian PT perseorangan oleh badan hukum.

\section{b. United Kingdom}

United Kingdom (UK) mempunyai
pengaturan mengenai SMC atau PT
perseorangan UK Companies Act 2006.
Pengaturan mengenai SMCmerupakan bagian dari reformasi hukum perusahaan yang dijalankan oleh UK selain tentunya dalam rangka pemenuhan ketentuan EU terkait hukum perusahaan. ${ }^{38}$ Bahkan, reformasi hukum perusahaan di negara ${ }^{39}$ ini disebutkan langsung dalam Preamble UK Company Act 2006 yaitu:

"An Act to reform company law and restate the greater part of the enactments relating to companies; to make other provision relating to companies and other forms of business organisation; to make provision about directors' disqualification, business names, auditors and actuaries; to amend Part 9 of the Enterprise Act 2002; and for connected purposes." 40

Dalam UK Companies Act 2006, PT perseorangan dikenal dengan istilah Private Limited Company (Limited or Ltd). Setiap pendirian perusahaan ini harus dimasukkan dalam registrasi pemegang saham perusahaan dengan nama dan alamat tunggal. Regist ini kemudian harus dilengkapi pernyataan bahwa perusahaan hanya mempunyai satu orang pemegang saham. ${ }^{41}$ Perusahaan yang didirikan kemudian diregistrasikan secara daring/elektronik, melalui agen, atau secara fisik datang ke UK Companies House. Dengan biaya registrasi sebesar $£ 12$ (dua belas poundsterling UK), pengesahan badan hukum dapat diperoleh perusahaan dalam waktu sekitar 4-5 hari setelah diterima dengan lengkap berkasnya oleh UK Companies House. $^{42}$

Dalam hal kepemilikan atau pemegang saham, tidak disebutkan dalam UU perusahaan UK apakah Private Limited Company bisa didirikan hanya oleh orang individual atau boleh juga oleh badan hukum atau usaha. UK Company Act 2006 hanya menyebut "person" tanpa membedakan natural person atau legal person. Dalam hal ini, pendirian atas Private Limited Company dimungkinkan oleh suatu body corporate atau badan usaha lain. Hanya dalam konteks direksi saja bahwa posisi ini hanya bisa diisi oleh orang individual atau natural person. Dalam hal Private Limited

38 Paul Omar, "In the Wake of the Companies Act 2006: An Assessment of the Potential Impact of Reforms to Company Law", International Company and Commercial Law Review, 20 (2), 2009,hlm. 44-55: hlm. 44 \& 54.

39 UK menempati peringkat ke-18 dalam hal memulai berusaha (starting a business). Lihat World Bank Group (2), Doing Business 2020: Economy Profile United Kingdom, https://www.doingbusiness.org/content/dam/ doingBusiness/country/u/united-kingdom/GBR.pdf, hlm. 4-9, (diakses pada 1 Februari 2020).

40 Lihat Preambul dari UK Companies Act 2006 (Chapter 46). Undang-undang perusahaan UK merupakan UU dengan jumlah pasal terbanyak yang disahkan oleh parlemen UK dimana UU ini terdiri dari 47 bagian (part) dan 1300 pasal (sections) yang kemudian dilengkapi 16 lampiran (schedules). UU ini merupakan "omnibus law" yang menggantikan sebagian besar ketentuan dalam the Companies Act 1985, Companies Act 1989 and Companies (Audit, Investigations and Community Enterprise) Act 2004. Dalam Preambul UU ini pun tersebut Enterprise Act 2002 yang ikut diamandemen. Lihat Paul Omar, loc.cit., p. 44.

$41 \quad$ Pasal 123 UK Companies Act 2006.

42 Gov UK, "Register your Company", Part of Set Up a Limited Company: Step by Step, https://www.gov.uk/limitedcompany-formation/register-your-company, (diakses 11 Februari 2020). Lihat juga World Bank Group (2), loc. cit. 
Company, tentusaja posisi satu orang direksi dalam perusahaan ini hanya bisa diisi oleh natural person. ${ }^{43}$

Susunan organisasi Private Limited Company terdiri dari apat mum emegang aham (RUPS) dan direksi. RUPS ini hanyalah terdiri dari satu orang pemegang saham. ${ }^{44}$ Pemegang saham Private Limited Company dapat menyelenggarakan RUPS dan kehadirannya dalam RUPS dianggap kuorum. ${ }^{45}$ Keputusan atas perusahaan dapat diambil oleh pemegang saham dan dijalankan oleh direksi serta karyawan perusahaan.

SMC tidak disyaratkan modal minimumnya dalam UK Companies Act 2006. Dalam hal ini, SMC ini dapat didirikan dengan modal berapapun agar bisa menjalankan usahanya. Jenis perusahaan ini boleh masuk dalam berbagai bidang usaha kecuali dalam sektor tertentu misalnya asuransi, perbankan, penerbitan uang elektronik, dan investasi. ${ }^{46}$ Sektor-sektor barusan hanya diperuntukkan bagi perusahaan yang dimiliki lebih dari satu pihak secara publik.

Pada dasarnya setiap SMCtidak dapat menawarkan saham-sahamnya kepada publik atau membagi saham-sahamnya kepada pihak lain dengan alasan penawaran publik. ${ }^{47}$ Pengecualian atas hal ini adalah apabila perusahaan menawarkan sahamnya kepada orang lain yang sebelumnya sudah dikenal atau terkoneksi dengan perusahaan (persons already connected with company) seperti keluarga pemegang saham atau karyawan, karyawan perusahaan yang bersangkutan, kreditur, atau trustee dari perusahaan yang bersangkutan. ${ }^{48}$ Pengecualian lainnya adalah jika perusahaan dengan itikad baik berniat untuk menjadi perusahaan publik dengan menawarkan saham-sahamnya kepada publik atau perusahaan melakukan registrasi ulang sebagai perusahaan publik. ${ }^{49}$ Dalam hal terakhir ini, maka perusahaan berjenis Private Limited Company sudah siap mengkonversikannya sebagai perusahaan publik (Public Limited Companies).

Serupa dengan konversi Private Limited Company atau SMC menjadi Public Limited Companies, perusahaan publik yang pemegang sahamnya tersisa hanya satu orang saja harus melakukan registrasi ulang untuk menjadi Private Limited Companies. ${ }^{50}$ Apabila perusahaan lalai dalam mematuhi registrasi ulang ini, maka akan dianggap sebagai pelanggaran (offence), ${ }^{51}$ denda maksimal $£ 1000$ (seribu poundsterling UK) menjadi sanksi atas pelanggaran ini. ${ }^{52}$ Apabila pelanggaran berlanjut maka perusahaan atau karyawannya dikenakan sanksi pidana denda harian maksimal $1 / 3$ (sepertiga) dari nilai tadi. $^{53}$

\footnotetext{
43 Pasal 55 UK Companies Act 2006.

44 International Business Publication USA, United Kingdom Business Law Handbook (Volume 1: Strategic Practical Information and Contact), (Wahington: International Business Publication USA, 2010), hlm 74.

45 Pasal 318 UK Companies Act 2006.

46 Pasal 384 ayat (1) UK Companies Act 2006.

$47 \quad$ Pasal 755 ayat (1) UK Companies Act 2006.

48 Pasal 756 ayat (4) dan ayat (5) UK Companies Act 2006.

49 Pasal 90 ayat (1) dan 755 ayat (3) UK Companies Act 2006.

50 Pasal 123 ayat (2) UK Companies Act 2006.

51 Pasal 123 ayat (2) UK Companies Act 2006.

52 Pasal 37 Criminal Justice Act 1982.

53 Pasal ayat (5) UK Companies Act 2006 jo. Article 37 Criminal Justice Act 1982.
} 


\section{c. Malaysia}

Tahun ini Malaysia berada pada peringkat ke-12 dalam kemudahan berusaha (EoDB). Sementara Indonesia berada di peringkat ke73. Banyak hal yang telah disiapkan pemerintah Malaysia dalam rangka meningkatkan EoDB dimana salah satunya adalah pengaturan mengenai PT yang dimiliki oleh perseorangan. Malaysia mempunyai pengaturan mengenai SMC atau PT perseorangan sudah sejak 1965 (Companies Act 1965) dan kemudian dipertahankan ketika disahkannya Companies Act2016 (Act 777). Perusahan perseorangan tersebut bernama "Sdn. Bhd." Yang berasal dari singkatan Sendirian Berhad (Perusahaan Terbatas Perorangan). ${ }^{54}$ Sdn. Bhd. dapat didirikan minimal 1 (satu) orang dengan maksimal pemegang saham adalah 50 (lima puluh) pemegang saham. Pendirian dilakukan dengan permohonan pengajuan nama perusahaan, pengajuan pendaftaran dan perolehan status badan hukum secara online. ${ }^{55}$ Dengan demikian, pengajuan pendaftaran dan perolehan status badan hukum dilakukan secara online, kemudian didaftarkan dan setelah disetujui badan hukumnya kemudian diterbitkan ertifikat adan ukumnya. Dari segi modal, tidak ditentukan modal minimumnya, untuk bidang usaha juga tidak ada pembatasan. Organ perusahaan terdiri dari minimal 1 (satu) orang anggota dan minimal 1 (satu) orang Direksi. Terkait tanggung jawab perusahaan, setiap anggota tidak akan bertanggung jawab atas kewajiban perusahaan hanya dengan alasan menjadi anggota perusahaan. ${ }^{56}$ Tanggung jawab anggota perusahaan terbatas pada: (1) dalam hal perusahaan dibatasi oleh saham, jumlah berapapun saham yang belum dibayarkan yang dipegang oleh anggota; (2) tanggung jawab apapun yang secara tegas diatur dalam anggaran dasar perusahaan. Suatu Perusahaan Perorangan dapat dikonversi menjadi Perusahan Publik dengan resolusi khusus. Kewenangan Perusahaan berada pada Suruhanjaya Syarikat Malaysia (SSM) atau Komisi Perusahaan Malaysia.

\section{d. Singapura}

Saat ini Singapura berada pada peringkat ke-2 dalam kemudahan berusaha (EoDB). Singapura merupakan negara favorit tujuan perusahaan-perusahaan global untuk perpanjangan tangan bisnis mereka di Asia. Kemudahan berbisnis menjadi poin utama bagi Negeri Singa ini. Menurut pendiri Singapore Guidebook, Tatiana Gremenko, sudah sejak lama Singapura dipilih sebagai destinasi bisnis untuk industri jasa, terutama bagi perusahaan rintisan (startup) digital berbasis teknologi. Terobosan yang dilakukan diantaranya adalah mengadakan berbagai macam gelaran yang mengumpulkan beragam perusahaan kelas dunia dan asia, termasuk diantaranya adalah temu investor. Hal ini menarik minat para startup lokal untuk berkompetisi di Singapura. Salah satu pertimbangan bagi investor untuk berbisnis di Singapura adalah regulasi yang dikeluarkan

\footnotetext{
Pasal 25 ayat (1) huruf b Malaysia Companies Act 2016.

55 Lihat Suruhanjaya Syarikat Malaysia, "Incorporation of Company under the Companies Act,2016",https://www. ssm.com.my/Pages/Register_Business_Company_LLP/Company/Starting_Company.aspx, (diakses pada 13 November 2020).

56 Pasal 192 Ayat (1) Malaysia Companies Act 2016
} 
pemerintah ramah terhadap usaha. Pemerintah Singapura sangat menyadari dengan potensi yang dimilikinya, dimana posisi greografisnya sangat strategis di Asia. Oleh karena itu, pemerintah Singapura sangat mengakomodir perusahaan-perusahaan asing yang ingin penetrasi di kawasan regional diantaranya melalui regulasi yang ramah dan iklim bisnis yang kondusif. Selain itu, kebijakan pajak negara ini bersifat terbuka dan bahkan memberikan pembebasan pajak serta insentif keuangan. ${ }^{57}$

Salah satu perbandingan regulasi adalah terkait pengaturan perusahaan perorangan terbatas di Singapura. Dasar hukum pengaturannya diatur dalam Singapore Companies Act (Chapter 50) Act 42/1967 dan terakhir diubah pada tahaun 2006. Istilah penamaan hampir sama dengan Malaysia yaitu Perusahaan Perorangan, Perusahaan Terbatas (Pte Ltd), Sendirian Berhad. Perusahaan yang memliki modal saham dapat dimasukkan sebagai perusahaan swasta jika konstitusinya: (1)membatasi hak untuk mentransfer sahamnya; dan (2)membatasi tidak lebih dari 50 jumlah anggotanya. Kepemilikan saham terdiri antara 1-50 pemegang saham dan adanya pembatasan terhadap pemindahan saham, sementara gabungan dari pemegang saham dianggap sebagai satu pihak. ${ }^{58}$ Mekanisme pendiriannya adalah dengan mengajukan permohonan pengajuan nama perusahaan, pengajuan pendaftaran dan perolehan status badan hukum secara online. ${ }^{59}$ Dalam hal pendaftaran atau pengesahan badan hukum, mekanismenya adalah melakukan pengajuan pendaftaran dan perolehan status badan hukum secara online, didaftarkan setelah disetujui status badan hukumnya dan kemudian diterbitkan sertifikat persetujuan badan hukumnya. Modal minimum tidak disyaratkan dalam pendirian perusahaan dan tidak ada juga pembatasan bidang usaha. Sementara itu, jumlah organ perusahaan minimal 1 orang anggota dan minimal 1 orang Direksi. Rapat terdiri dari rapat tahunan dan rapat luar biasa. Berkaitan dengan pertanggungjawaban, tanggung jawab anggota adalah terbatas, yaitu terbatas pada jumlah, jika ada, dan tidak dibayarkan pada saham yang masingmasing dimiliki. Perusahaan perorangan dapat berubah status menjadi perusahaan publik jika diatur dalam anggaran dasarnya. Sementara itu, kewenangan perusahaan berada pada Otoritas Akuntansi dan eraturan erusahaan yang berada di bawah Menteri Keuangan Singapura.

\section{Peluang, Tantangan, dan Usulan Pengaturan PT Perorangan di Indonesia}

Pengusulan mengenai pengaturan model PT perseorangan di Indonesia tentu akan menghasilkan peluang dan tantangan. Kemudahan dalam membuat perusahaan bagi UMK tanpa prosedur yang kompleks dan biaya yang tinggi disertai tanggung jawabnya yang terbatas menjadi kelebihan atau peluang dari hadirnya usulan PT

\footnotetext{
57 https://ekonomi.bisnis.com/read/20191103/9/1166326/singapura-jadi-negara-favorit-para-pebisnis-duniaini-sebabnya, (diakses pada tanggal 14 februari 2020)

58 Singapore Companies Act, Pasal 18.

59 Lihat Accounting and Corporate Regulatory Authority, "Setting Up a Local Company", https://www.acra.gov.sg/ how-to-guides/setting-up-a-local-company, (diakses pada 14 Februari 2020)
} 
perseorangan. PT biasa yang didirikan oleh dua orang atau lebih dipersepsikan sebagai PT yang didesain untuk usaha yang lebih besar dan multinasional. ${ }^{61}$ Peluang lainnya adalah bahwa status PT perseorangan tidak mungkin lagi dibedakan apakah dia perusahaan perorangan biasa atau grup dari suatu perusahaan besar. ${ }^{62}$ PT perseorangan yang merupakan UMK dapat memainkan peran penting dalam mempromosikan investasi dan pengembangan ekonomi. Lebih lanjut, hadirnya PT perseorangan dapat meletigimasi situasi umum yang ada yaitu bahwa PT biasa didirikan oleh dua orang namun dalam kenyataannya hanya dijalankan atau dikendalikan oleh satu orang. Pemegang saham lainnya bersifat pasif atau hanya "numpang nama" agar bisa memenuhi persyaratan minimal dua pemegang saham. PT perseorangan pun dapat menghindari risiko sengketa antar pemegang saham. Dengan model PT ini, pemegang saham dapat mengambil keputusan atas bisnisnya secara cepat dan efisien.

Sementara itu, risiko perbuatan melawan hukum atau kejahatan PT perseorangan dianggap menjadi kelemahan dan tantangan dari model PT ini. Hal ini mengingat bahwa PT didirikan dan dikendalikan oleh satu pemegang saham saja dan terbuka lebar kemungkinan adanya fraud yang dilakukan oleh pemegang saham yang bersangkutan terhadap pihak ketiga dengan memanfaatkan terbatasnya tanggung jawab. ${ }^{63}$ Walaupun demikian, konsep piercing the corporate veil atau lifting the veilbisa diberlakukan karena bagaimanapun PT perseorangan adalah bagian dari bentuk hukum PT. ${ }^{64}$ Cara lain yang bisa diberlakukan adalah misalnya penerapan ketentuan mengenai penyetoran modal penuh melalui bank seperti yang dilakukan di Italia sebagai jaminan PT atau menerapkan modal minimum pendirian PT seperti yang dilakukan di Jerman. ${ }^{65}$

Bagaimana seharusnya pengaturan PT perseorangan di Indonesia agar bisa memudahkan UMK di satu sisi namun juga tetap memberikan pelindungan bagi pihak ketiga atau kreditur di sisi lain? materi yang perlu diatur atau pengaturan yang secara garis besar bisa diusulkan, dengan mempertimbangkan studi perbandingan

61 Susanne Braun, The European Private Company: "A supranational Company Form for Small and Medium-sized Enterprises?",German Law Journal, 5(11), 1393-1608 dalam Beihui Mao, loc.cit., 2009, hlm. 3. Di Spanyol, kasus terkait piercing the corporate veil untuk PT Perseorangan tetap diputus oleh hakim bahwa pemegang saham tetap bertanggung jawab secara pribadi jika utang perseroan tidak cukup dibayar dari harta perseroan. Lihat J.M. Embid Irujo, The Groups of Companies in Spanish Law, hlm. 123-140, Chapter inside Eddy Wymeersch (ed), Group of companies in the EEC: "A Survey Report the Law relating to Corporate Gropus in VariousMember States", (Berlin-New York: de Gruyter, 1993), hlm. 138.

62 Muzaffer Eroglu, "Single Member Companies in Turkish Law", 64 Legal Hukum Dergisi 1269, http://dx.doi. org/10.2139/ssrn.1158421, hlm. 7-8, (diakses pada 11 Februari 2020).

63 Muzaffer Eroglu, loc.cit., hlm. 9.

64 Kasus Solomon v A Salomon Ltd yang terjadi di United Kingdom pada 1897 menjadi kasus benchmark dalam penerapan prinsip piercing the corporate veil atau lifting the veil di duniadan mempengaruhi pengaturan PTdi sejumlah negara. Kasus ini merupakan kasus dimana kreditur merasa dirugikan dengan likuidasi Salomon Ltd, dimana orang yang bernama Salomon merupakan pemegang sajam mayoritas. Salomon berlindung kepada tanggung jawab terbatas untuk menghindari hutang-hutang yang dibuatnya dengan kreditur pada saat likuidasi perusahaan. Lihat Salomon v A Salomon Co Ltd [1896] UKHL 1, [1897] AC 22. Penjelasan lengkap kasusnya ada pada pranala berikut: https://www.bailii.org/uk/cases/UKHL/1896/1.html.

65 Muzaffer Eroglu, loc.cit., hlm. 11. 
dengan negara-negara tadi dan karakteristik PT di Indonesia, adalah sebagai berikut ini:
1. Pendefinisian yang jelas atas PT perseorangan;

2. Persyaratan pendiri dan pemegang saham;

3. Persyaratan permodalan minimum dan penyetoran modal;

4. Penerapan ketentuan deposit atau jaminan melalui modal yang disetorkan;

5. Proses pendirian dan pengesahan badan hukum serta pembubaran/likuidasi;

6. Organ perusahaan beserta peran tanggung jawab;

7. Pelaporan perusahaan; dan

8. Peralihan status dan prosedurnya.

Pengertian mengenai PT perseorangan perlu didefinisikan dengan jelas. Dalam UU No. 40/2007 tentang Perseroan Terbatas (UUPT), yang dimaksud dengan PT adalah badan hukum yang merupakan persekutuan modal, didirikan berdasarkan perjanjian, melakukan kegiatan usaha dengan modal dasar yang seluruhnya terbagi dalam saham dan memenuhi persyaratan yang ditetapkan dalam undang-undang ini serta peraturan pelaksanaannya. ${ }^{66}$

Definisi PT dalam UUPT masih menunjukkan bahwa PT hanya bisa didirikan oleh dua orang atau lebih. Hal ini termakna dari frasa "berdasarkan perjanjian" dimana perjanjian sudah pasti dilakukan oleh minimal 2 (dua) orang. Untuk itu, perlu ada perubahan definisi atas PT agar bisa mengakomodasi pendirian usaha yang dilakukan oleh minimal satu orang dan terdiri dari minimal satu pemegang saham.

Dalam konteks pendiri atau pemegang saham, pendiri PT perseorangan hanya bisa dilakukan oleh orang pribadi atau individu. PT perseorangan tidak boleh didirikan oleh badan hukum. Hal ini mengingat bahwa PT ini ditujukan untuk Usaha Mikro dan Kecil (UMK). Hal ini pun sejalan dengan kategori UMKM dalam UU No. 20/2008 tentang UMKM yang menentukan bahwa UMKM bukanlah grup dari perusahaan menengah dan besar. ${ }^{67}$ Dalam hal PT perseorangan hendak mendirikan usaha di bawahnya atau menjadi pemegang saham PT lainnya, hal itu sebaiknya diperbolehkan. Namun demikian, usaha yang didirikan dan saham yang dipegang tidak diperbolehkan berbentuk PT perseorangan lagi. Hal ini konsisten dengan usulan mengenai pendiri PT perseorangan yang hanya berasal dari orang pribadi.

Pendiri PT perseorangan diperbolehkan untuk mendirikan PT perseorangan lagi selain PT perseorangan yang sudah dimiliki. Namun, pendirian ini hanya bisa dilakukan setelah jangka waktu tertentu setelah pendirian/ pengesahan badan hukum PT perseorangan sebelumnya, misalnya paling cepat atau minimal 1 (satu) tahun. Hal ini agar tidak menjadikan pelaku usaha memanfaatkan kesempatan kemudahan ini dengan itikad tidak baik dan berpotensi melakukan perbuatan melawan hukum.

Modal dasar minimum perusahaan diserahkan kepada pendiri atau pemegang

66 Indonesia (1), Undang-Undang tentang Perseroan Terbatas, Undang-Undang No. 40/2007, Lembaran Negara RI Tahun 2007 No. 106, Tambahan Lembaran Negara RI No. 4756.

67 Lihat definisi Usaha Kecil dan Usaha Menengah dalam Pasal 1 angka 2 dan angka 3 UU No. 20/2008 tentang UMKM. Indonesia (2), Undang-Undang tentang Usaha Mikro Kecil dan Menengah, Undang-Undang No. 20/2008, Lembaran Negara RI Tahun 2008 No. 93, Tambahan Lembaran Negara RI No. 4756. 
sahamnya dan tertuang dalam anggaran dasar perusahaan tersebut. Hal ini pun sejalan dengan semangat UUPT dan PP No. 29/2016 tentang Perubahan Modal Dasar Perseroan Terbatas. PP tersebutmenentukan bahwa penentuan modal dasar diserahkan kepada kesepakatan para pendiri PT. ${ }^{68}$

Terkait dengan penyetoran modal, PT perseorangan sebaiknya diharuskan melakukan penyetoran penuh atas modal sesuai jumlah modal yang ditentukan oleh dirinya saat pendirian. ${ }^{69}$ Setoran modal dilakukan oleh pendiri atau perusahaan ke bank. Modal yang disetor ini dapat menjadi "deposit" atau "jaminan" manakala terdapat tuntutan pihak ketiga kepada PT perseorangan. Untuk memberikan keseimbangan bagi operasional perusahaan dan pelindungan pihak ketiga, terhadap PT perseorangan perlu diatur persentase tertentu yang mungkin bisa menciptakan keseimbangan tersebut. Dalam kaitan pengelolaan jaminan atau deposit ini, perlu dibentuk lembaga khusus apakah di bawah Kementerian Hukum dan Hak Asasi Manusia dan Kementerian Koperasi dan Usaha Kecil dan Menengah (UKM) misalnya dalam bentuk Badan Layanan Umum (BLU) atau apakah badan hukum publik yang bersifat independen. BLU atau badan hukum publik ini bisa berperan layaknya Lembaga Penjamin Simpanan (LPS) yang bisa membayarkan klaim kepada pihak ketiga ketika terjadi sengketa atau gugatan dari pihak ketiga. Untuk mendukung implementasi ini, lembaga keuangan seperti bank mempunyai kewajiban dalam turut menerima deposit atau jaminan dan kemudian menyetorkannya kepada BLU atau badan hukum publik yang mengelola deposit atau jaminan PT perseorangan.

Proses pendirian dan pengesahan badan hukum PT perseorangan harus lebih mudah daripada pendirian PT biasa. Dengan peruntukkan untuk UMK dan didirikan oleh satu orang pemegang saham, pendirian PT ini dapat dilakukan dengan cara membuat pernyataan pendirian dan mengisi formulir langsung secara daring melalui platformlaman web atau aplikasi telepon genggam. Pendirian ini juga bisa dilakukan dengan mendatangi kantor kementerian atau kantor wilayah kementerian terkait untuk memperoleh bantuan pelayanan pendirian. Bahkan, bantuan pihak ketiga perlu juga dibuka untuk mengakomodasi pelaku UMK. Proses pengesahan badan hukum sebaiknya cepat (dalam hitungan jam atau maksimal 1 hari) setelah seluruh isian formulir dan dokumen yang disyaratkan lengkap serta telah melakukan pembayaran biaya pendirian. Pelaku UMK bertanggung jawab penuh atas kebenaran informasi yang disampaikan dalam isian formulir yang disampaikannya.

Serupa dengan pendirian, proses pembubaran pun juga perlu dibuat yang sederhana dan dilakukan secara elektronik. Namun demikian, proses likuidasi dan pemberesan perusahaan tetap harus mengikuti UUPT yang berlaku. Hal ini karena berhubungan dengan pihak kreditur atau pihak ketiga. Tentu saja, pelaku UMK tidak 
boleh mengelak dari tuntutan pihak kreditur/ pihak ketiga, jika ada.

Dalam hal organ perusahaan, PT perseorangan sebaiknya tetap mempunyai susunan organ yang sama dengan PT biasa yaitu RUPS, Direksi, dan Dewan Komisaris, meskipun ketiga organ tersebut dipegang oleh orang yang sama. Hal ini perlu dituangkan jelas dalam pernyataan pendirian PT perseorangan dan juga perubahan komposisinya jika ada. Sejalan dengan jumlah pemegang saham yang satu orang, maka jumlah minimum direksi dan komisaris adalah masing-masing 1 (satu) orang. Tanggung jawab direksi (fiduciary duty) dan dewan komisaris adalah dipersamakan dengan tanggung jawab pada PT biasa. $^{70}$ Dalam hal penyelenggaraan RUPS, pengaturan mengenai pemanggilan RUPS bisa dibuat dengan tenggat waktu pemanggilan yang lebih fleksibel mengingat jumlah pemegang saham yang akan berpartisipasi hanya satu orang. ${ }^{71}$

Pengaturan kuorum dan pengambilan keputusan pun diatur secara berbeda dimana kehadiran pemegang saham tunggal dianggap sebagai kuorumdan dia bisa mengambil keputusan atas perusahaanya.
Serupa dengan kewajban pelaporan PT pada umumnya, PT perseorangan melalui direksinya juga harus mempunyai kewajiban penyampaian laporan tahunan dengan ketentuan jangka waktu penyampaian yang berbeda misalnya yaitu 3 (tiga) bulan setelah tahun buku perseroan berakhir. ${ }^{72}$ Materi laporan tahunan untuk PT perseorangan sebaiknya disesuaikan dengan karakter pelaku UMK, misalnya laporan keuangan berupa laporan laba rugi, kegiatan perseroan, dan nama direksi/komisaris/pemegang saham. Bentuk format pelaporan pun sebaiknya juga dipermudah dengan cara menyediakan isian formulir laporan secara daring. Pelaporan PT perseorangan tidak hanya disampaikan kepada pemegang saham, namun juga kepada publik melalui isian formulir laporan yang disediakan otoritas. Model pelaporan ini dikenal dengan istilah annual return, annual filling, atau confirmaton statement. ${ }^{73}$ PT perseorangan yang bersangkutan bertanggung jawab penuh atas kebenaran isi laporan tahunan.

Terkait dengan peralihan status dari PT perseorangan ke PT biasa, indikator yang bisa digunakan adalah indikator yang berasal dari kriteria UMKM dalam UU No. 20/2008

70 Direksi mempunyai peran dalam menjalankan perusahaan dan pengurusan perusahaan dengan penuh itikad baik dan tanggung jawab untuk kepentingan perseroan dan sesuai dengan maksud dan tujuan perseroan. Hal ini sesuai dengan prinsip duty of care (menjalankan pengurusan), duty of loyalty (penuh itikad baik dan tanggung jawab), dan duty of obedience (sesuai misi perseroan). Direksi juga harus bertanggung jawab penuh secara pribadi atas kerugian perseroan manakala melanggar prinsip-prinsip tadi. Hal ini termakna dari Pasal 92 dan Pasal 95 UUPT. Sementara itu, Dewan Komisaris berperan dan bertanggung jawab dalam hal pengawasan atas kebijakan pengurusan perusahaan oleh direksi dan memberi nasihat kepada Direksi dengan itikadi baik, penuh kehati-hatian, dan tanggung jawab. Sama halnya dengan direksi, komisaris juga bertanggung jawab secara pribadi atas kerugian perseroan manakala lalai atau bersalah dalam menjalankan tugasnya. Hal ini termakna dari Pasal 108 dan 114 UUPT.

71 Pemanggilan RUPS dalam PT biasa ditentukan dalam jangka waktu paling lambat 14 (empat belas) hari sebelum tanggal RUPS diadakan melalui surat tercatat dan/atau iklan di surat kabar. Lihat Pasal 82 UUPT.

72 PT pada umumnya mempunyai tenggat waktu penyampaian paling lambat 6 (enam) bulan. Lihat Pasal 66 ayat (1) UUPT.

73 Istilah Annual Return dikenal di berbagai negara terkait kewajiban PT menyampaikan laporan tahunannya kepada otoritas, contohnya Singapura. Istilah annual filling dikenal di Belanda, sedangkan confirmation statement dikenal di United Kingdom. 
tentang UMKM. Dalam UU tersebut, maksimal kekayaan bersih usaha mikro adalah Rp 50juta, dengan maksimal penjualan tahunan sampai dengan Rp 300juta. ${ }^{74}$ Sementara itu, maksimal kekayaan bersih usaha kecil adalah Rp500 juta, dengan maksimal penjualan tahunan sampai dengan Rp2,5 miliar. $^{75}$ Manakala PT perseorangan mencapai lebih dari salah satu kekayaan bersih atau penjualan tahunan UMK dan masuk kategori menengah, maka PT yang bersangkutan wajib mengubah dirinya menjadi PT biasa dengan minimal pemegang saham berjumlah 2 (dua) orang. Perusahaan wajib mengkonversi bentuknya sebaiknya paling lambat 30 (tiga) puluh hari setelah penyampaian laporan tahunan dan setelah diketahui bahwa usahanya sudah masuk kategori usaha menengah.

Dalam hal konversi dari PT biasa menjadi PT perseorangan, hal ini sebaiknya harus dilakukan ketika jumlah pemegang saham menjadi 1 (satu) orang. Berbeda dengan konversi PT perseorangan menjadi PT biasa, indikator soal kekayaan bersih dan penjualan tahunan tidak perlu diberlakukan dalam hal konversi PT biasa kepada PT perseorangan. Oleh karenanya, meski terdapat penurunan kekayaan bersih dan penjualan tahunan hingga masuk kategori UMK, PT biasa tidak dapat mengubah dirinya menjadi PT perseorangan. Konversi hanya bisa dilakukan ketika jumlah pemegang sahamnya berkurang menjadi hanya satu orang.

\section{Penutup}

Dari pembahasan yang sudah diuraikan dalam bagian sebelumnya, penulis menarik kesimpulan bahwa Pemerintah menyusun RUU Cipta Kerja salah satunya adalah untuk mendorong kemudahan berusaha bagi Usaha Mikro Kecil dan Menengah selain bertujuan untuk kemudahan investasi, terlepas dari kontroversi penyusunan RUU yang ada. Salah satu bentuk kemudahan berusaha yang diusulkan adalah pengaturan mengenai PT perseorangan yang khusus ditujukan bagi pelaku UMK. Sejumlah negara seperti UK, negara-negara EU, Malaysia, dan Singapura sudah mengatur kebolehan mengenai pendirian PT oleh seorang pemegang saham. Pengaturan terkait SMC yang ada di UK, EU, Malaysia, dan Singapura diantaranya meliputi kriteria pendiri, organ perusahaan, permodalan, rapat-rapat, dan peralihan status. Pengaturan serupa dimungkinkan di Indonesia disertai dengan peluang kemudahan berusaha bagi UMK dan tantangan pelindungan kreditur/pihak ketiga. Untuk itu, penyusunan aturan atau regulasi PT perseorangan yang berkualitas adalah keniscayaan untuk menyeimbangkan kepentingan kemudahan berusaha dan pelindungan pihak ketiga/kreditur serta masyarakat.

Sehubungan dengan kesimpulan yang diuraikan tadi, maka rekomendasi pengaturan bagi PT perseorangan setidaknya meliputi: (1) pendefinisian yang jelas atas PT perseorangan; (2) persyaratan pendiri dan pemegang saham; (3) persyaratan permodalan minimum dan penyetoran modal; (4) penerapan ketentuan deposit atau jaminan melalui modal yang disetorkan; (5) proses pendirian dan pengesahan badan hukum; (6) organ

74 Lihat Pasal 6 ayat (1) UU UMKM.

75 Lihat Pasal 6 ayat (2) UU UMKM. 
perusahaan beserta peran tanggung jawab; (7) pelaporan perusahaan; dan (8) peralihan status dan prosedurnya. Uraian lengkap rekomendasi pengaturan telah dijabarkan pada bagian sebelumnya.

\section{Daftar Pustaka}

\section{Buku}

Asikin, Zainal \& Wira Pria Suhartana, Pengantar Hukum Perusahaan, Edisi Pertama, (Jakarta: Prenada Media Group, 2016).

Chewaka, Jetu Edosa, Introducing Single Member Companies in Ethiopia: Major Theoritical and Legal Considerations, (Hamburg: Anchor Academic Publishing, 2016).

International Business Publication USA, United Kingdom Business Law Handbook (Volume 1: Strategic Practical Information and Contact), (Wahington: International Business Publication USA, 2010).

Irujo, J.M. Embid, The Groups of Companies in Spanish Law, hlm. 123-140, Chapter inside Eddy Wymeersch (ed), Group of companies in the EEC: "A Survey Report the Law relating to Corporate Gropus in VariousMember States", (Berlin-New York: de Gruyter, 1993).

Raharjo, Hendri, Hukum Perusahaan, Cetakan Ke-1, (Yogyakarta: Penerbit Pustaka Yustisia, 2009).

Roney, Alex, EC/EU Fact Book, 6 Edition, (London: Kogan Page, 2000).

Soekardono, Hukum Dagang Indonesia: Jilid I (Bagian Pertama), Cetakan ke-9, (Jakarta: Dian Rakyat, 1982).

Sutedi, Adrian, Buku Pintar Perseroan Terbatas, Cetakan Ke-1, (Jakarta: Raih Asas Sukses, 2005).

World Bank Group(1), Doing Business 2020: Comparing Business Regulation in 190 Economies, (Washington: The World Bank, 2020).

Yani, Ahmad dan Gunawan Widjaja, Seri Hukum Bisnis: Perseroan Terbatas, (Jakarta: Raja Grafindo Persada, 2006).

\section{Makalah/Artikel/Prosiding/Hasil Penelitian}

Braun, Susanne, The European Private Company: "A supranational Company Form for Small and Medium-sized Enterprises?",German Law Journal, 5(11), 1393-1608 dalam Beihui Mao, (2009).

Commission of The European Communities, Proposal for a Twelfth Council Directive on Company Law Concerning Single-Member Private Limited Companies, COM(88) 101 final-SYN 135, (Brussels, 18 May 1988).

Omar, Paul, "In the Wake of the Companies Act 2006: An Assessment of the Potential Impact of Reforms to Company Law", International Company and Commercial Law Review, 20 (2), (2009).

Parikesit, Satya Bhakti, "Penjelasan RUU Cipta Kerja", (Makalah Disampaikan pada Seminar Menyikapi Omnibus Law, Pro dan Kontra RUU Cipta Lapangan Kerja, Fakulta Hukum Universitas Indonesia, Depok, 6 Februari 2020).

\section{Internet}

The Law Dictionary, What is Omnibus Bill, Featuring Black's Law Dictionary Free Online Legal Dictionary $2^{\text {nd }}$ Edition, https:// thelawdictionary.org/omnibus-bill/, (diakses pada 31 Januari 2020).

Hendra Friana, "Jokowi Ajak DPR Buat UU Cipta Lapangan Kerja \& UU Pemberdayaan UMKM", Tirto, 20 Oktober 2019, https://tirto.id/ jokowi-ajak-dpr-buat-uu-cipta-lapangankerja-uu-pemberdayaan-umkm-ej5G, (diakses pada 3 Februari 2020).

Rakyat Merdeka, "Dorong Iklim Investasi dan Daya Saing RI, Omnibus Law", RMcoid, Selasa, 24 Desember 2020, https://rmco.id/bacaberita/government-action/25164/dorongiklim-investasi-dan-daya-saing-ri-omnibuslaw-segera-dirampungkan, (diakses pada 6 Februari 2020).

Adhy Tea, 12 Alasan Masyarakat Sipil Tolak RUU Cipta Lapangan Kerja, Hukum Online, Sabtu 1 Februari 2020, https://www.hukumonline. $\mathrm{com} /$ berita/baca/lt5e3474fe03a84/12alasan-koalisi-masyarakat-sipil-tolak-ruucipta-lapangan-kerja/, (diakses pada 10 Februari 2020).

Kementerian Koperasi dan Usaha Kecil dan Menangah (UKM), "Perkembangan Data Usaha Mikro, Kecil, Menengah (UMKM) dan Usaha Besar (UB) tahun 2017-2018", http://www. depkop.go.id/uploads/laporan/1580223129 
PERKEMBANGAN\%20DATA\%20USAHA\%20 MIKRO,\%20KECIL, \% 20 MENENGAH\%20 (UMKM)\%20DAN\%20USAHA\%20BESAR\%20 (UB) \% 20TAHUN\%202017\%20\%202018. pdfhttp://www.depkop.go.id/uploads/ laporan/1580223129_PERKEMBANGAN\%20 DATA\%20USAHA\%20MIKRO,\%20KECIL,\%20 MENENGAH \% 20 ( U M K M ) \% 20 DAN\% 20 USAHA\%20BESAR\%20(UB)\%20TAHUN\%20 2017\%20-\%202018.pdf, (diakses pada 30 Januari 2020).

Badan Pengembangan Bahasa dan Perbukuan Kementerian Pendidikan dan Kebudayaan, Sero, KBBI Daring, https://kbbi.kemdikbud. go.id/entri/sero, (diakses pada 7 Februari 2020).

Beihui Mao, A Comparative Study of Legal Framework for Single Member Company in European Union and China, Journal of Politic of Law, Vol. 5(3) 2012, http://dx.doi. org/10.5539/jpl.v5n3p1, pp. 1-14: p.2.

Awais Aftab, "Company Regisration in Pakistan as Single Member Company", Oly, 1 Juni 2017, https://oly.com.pk/company-registrationpakistan-single-member-company/

World Bank Group (2), Doing Business 2020: Economy Profile United Kingdom, https:// www.doingbusiness.org/content/dam/ doingBusiness/country/u/united-kingdom/ GBR.pdf

Gov UK, "Register your Company", Part of Set Up a Limited Company: Step by Step, https://www. gov.uk/limited-company-formation/registeryour-company,(diakses 11 Februari 2020).

Suruhanjaya Syarikat Malaysia, "Incorporation of Company under the Companies Act 2016",https://www.ssm.com.my/Pages/ Register_Business_Company_LLP/Company/ Starting_Company.aspx, (diakses pada 13 November 2020).

h t t p s:// ekonom i.bis n s . com / read/20191103/9/1166326/singapura- jadi-negara-favorit-para-pebisnis-dunia-inisebabnya, (diakses pada tanggal 14 februari 2020).

Accounting and Corporate Regulatory Authority, "Settig Up a Local Company", https://www. acra.gov.sg/how-to-guides/setting-up-a-localcompany, (diakses pada 14 Februari 2020).

https://www.bailii.org/uk/cases/UKHL/1896/1. htm

\section{Peraturan}

Directive 2009/102/EC on the area of ompany law on single-member private limited liability companies yang mencabut Company Law Directive (89/667/EEC).

Directive 2009/102/EC of the European Parliament and of the Council of 16 September 2009 in the area of company law on single-member private limited liability companies. Lihat juga United Kingdom Companies Act 2006 (Chapter 46).

Indonesia, Undang-Undang tentang Perseroan Terbatas, UU No. 40 Tahun 2007, Lembaran Negara Tahun 2007 No. 106, Tambahan Lembaran Negara No. 4756.

Indonesia, Undang-Undang tentang Usaha Mikro Kecil dan Menengah, Undang-Undang No. 20/2008, Lembaran Negara RI Tahun 2008 No. 93, Tambahan Lembaran Negara RI No. 4756.

Indonesia (3), Peraturan Pemerintah tentang Perubahan Modal Dasar Perseroan Terbatas, PeraturanPemerintah No. 29/2016, Lembaran Negara RI Tahun 2016 No. 137

Malaysia Companies Act 2016 (Act 777).

Singapore Companies Act 1967 (Chapter 50), last amended in 2006.

Uganda, The Companies (Single Member) Regulations 2016, Statutory Instruments 2016 No. 72, The Uganda Gazette No. 79, Vol CIX, 18 November 2016 